\title{
Self reported rate of occupational asthma in Sweden 1990-2
}

\author{
Kjell Torén
}

\begin{abstract}
Objectives-To estimate the annual rates of self reported occupational asthma in different occupational groups in Sweden. Methods-All claims of occupational asthma 1990-2 in the Swedish register of reported occupational diseases were classified according to occupation. The number of people employed in each occupational group in the general population was obtained from the 1990 national census. Reporting rates (cases/million/ year) were calculated for each occupation with more than five reported cases, according to sex and age (20 to 64 years, and 20 to 44 years).
\end{abstract}

Results-1010 cases were reported giving an annual crude reporting rate of $80 / \mathrm{mil}$ lion $(95 \%$ confidence interval $(95 \%$ CI) 70 to 90$)$. For men, the crude reporting rate was $91 /$ million (95\% CI 84 to 98 ), and for women $70 /$ million ( $95 \%$ CI 80 to 106$)$. The highest reporting rates were among male bakers (775/million), furnacemen (702/million), male welders (647/million), female chemical and plastic production workers (629/million), and female poultry and dairy farm workers (602/million).

Conclusions-A surveillance system based on self reporting is influenced by considerable bias, especially reporting bias. However, results for the specific occupations with high rates were similar to those found with other surveillance systems. This indicates that our system is a useful one.

(Occup Environ Med 1996;53:757-761)

Keywords: epidemiology; surveillance; occupational asthma

Occupational asthma is probably the most common respiratory disorder caused by exposure in the workplace. The treatment of choice for occupational asthma is prevention. ${ }^{1}$ Primary prevention, which implies reduction or elimination of harmful exposures, is preferred. We deal mainly with secondary prevention, which means detection of workers with occupational asthma and subsequent removal from exposure. For successful preventive strategies we need knowledge about harmful exposures and about affected occupations. To establish this knowledge surveillance systems have been established in Finland, ${ }^{5}$ in the United Kingdom, ${ }^{3-5}$ and in the United States. ${ }^{6}$
They are based on reporting new cases of occupational asthma by clinicians in the field and have provided us with valuable information about incidences of occupational asthma in certain specific occupations-for instance, spray painters and bakers. However, the surveillance systems in the United Kingdom and the United States probably underestimate the incidence of occupational asthma. ${ }^{7}$ There may be many reasons for this, including unawareness of ordinary clinicians (and patients) of the importance of workplace exposure on asthma, and unwillingness of the patients to report connections with work, for fear of losing their job.

In Sweden there is a system for registration of the workers' own reports and claims about occupational asthma as well as other occupational diseases. ${ }^{8}$ A surveillance system based on self reporting may be very sensitive to bias compared with physician based systems. However, our knowledge in this field is limited and hence it is of interest to analyse and discuss the findings from the Swedish surveillance system.

\section{Methods}

All claims about occupational diseases are listed in the Swedish register of reported occupational diseases (SRROD). When claiming that they have an occupational disease workers have to complete a form with information about diagnosis, causes, current workplace, and some basic information about themselves, including their 10 digit unique personal identification number. The claim form has to be countersigned by the employer, and formally the employer is responsible for the claim reaching the regional national insurance office. In practice this transferral is made by the worker or the union. All claims are regularly registered in SRROD, but whether they are awarded or not is not registered. To award compensation, the subjects' asthma and connection with work must be certified by a physician, and accepted by the regional national insurance board.

All reported diseases and symptoms are classified according to the ninth international classification of diseases (ICD-9). For a disease to be classified as "asthma" the claimant must clearly state "asthma" on the claim form. The cases in this study consisted of all subjects, 20 to 64 years old, from SRROD who had filed claims for compensation for asthma during the years 1990-2.

Each subject has been classified according \\ Occupational Medicine and Allergy, Hospital, Göteborg, Dr Kjell Toren, Institute of Internal Medicine, Sec Occupational Medicine}


to occupational group (one or two digit code) or occupation (three digit code) based on the Nordic occupation classification (NYK82), which, in turn, is based on the international standard classification of occupations (ISCO). ${ }^{9}$ The number of workers in different

Table 1 Total number and annual self reporting rate (cases/million) of occupational asthma 1990-2 among Swedish men *

\begin{tabular}{|c|c|c|c|c|c|}
\hline \multirow[b]{2}{*}{$\begin{array}{l}\text { Digit } \\
\text { codet }\end{array}$} & \multirow[b]{2}{*}{$\begin{array}{l}\text { Occupation or } \\
\text { occupational group }\end{array}$} & \multicolumn{3}{|c|}{ Age 20-64 } & \multirow{2}{*}{$\frac{\text { Age } 20-44}{\text { Rate }(95 \% C I)}$} \\
\hline & & $n$ & Rate $(95 \% \mathrm{CI})$ & $\begin{array}{l}\text { Population } \\
(\times 1000)\end{array}$ & \\
\hline $\begin{array}{l}0 \\
00 \\
004 \\
004 \\
005 \\
03 \\
035\end{array}$ & $\begin{array}{l}\text { Professional technical } \\
\text { and related work } \\
\text { Technical work } \\
\text { Mechanical engineers } \\
\text { Chemical engineering } \\
\text { Educational work } \\
\text { Technical education } \\
\text { teachers }\end{array}$ & $\begin{array}{r}44 \\
24 \\
7 \\
15 \\
16\end{array}$ & $\begin{array}{c}40(28 \text { to } 52) \\
35(21 \text { to } 49) \\
32(8 \text { to } 56) \\
136(27 \text { to } 245) \\
67(34 \text { to } 101) \\
182(22 \text { to } 342)\end{array}$ & $\begin{array}{r}370 \\
228 \\
74 \\
15 \\
79 \\
9\end{array}$ & $\begin{array}{l}41(24 \text { to } 58) \\
16(3 \text { to } 29) \\
\overline{84}(0 \text { to } 200) \\
-\end{array}$ \\
\hline 1 & $\begin{array}{l}\text { Health, nursing, } \\
\text { and social work }\end{array}$ & 21 & $100(59$ to 147$)$ & 70 & $73(30$ to 117$)$ \\
\hline 2 & $\begin{array}{l}\text { Administrative, } \\
\text { managerial, and } \\
\text { clerical work }\end{array}$ & 7 & $10(3$ to 19$)$ & 230 & -.. \\
\hline $\begin{array}{l}3 \\
33\end{array}$ & $\begin{array}{l}\text { Sales work } \\
\text { Sales work (goods) }\end{array}$ & $\begin{array}{l}15 \\
13\end{array}$ & $\begin{array}{l}26(1 \text { to } 44) \\
31(14 \text { to } 48)\end{array}$ & $\begin{array}{l}190 \\
139\end{array}$ & - \\
\hline $\begin{array}{l}4 \\
40 \\
400 \\
44 \\
441\end{array}$ & $\begin{array}{l}\text { Agricultural, forestry, } \\
\text { and fishing work } \\
\text { Agricultural work } \\
\text { Farmers } \\
\text { Forestry work } \\
\text { Loggers }\end{array}$ & $\begin{array}{r}41 \\
24 \\
23 \\
9 \\
9\end{array}$ & $\begin{array}{l}152(115 \text { to } 210) \\
160(93 \text { to } 226) \\
179(106 \text { to } 252) \\
156(52 \text { to } 248) \\
165(57 \text { to } 273)\end{array}$ & $\begin{array}{l}90 \\
50 \\
43 \\
20 \\
18\end{array}$ & $\begin{array}{l}102(52 \text { to } 153) \\
127(41 \text { to } 224) \\
150(46 \text { to } 254) \\
-\end{array}$ \\
\hline 5 & $\begin{array}{l}\text { Mining, quarrying, } \\
\text { and petroleum } \\
\text { extraction work }\end{array}$ & 4 & 1333 (26 to 2600 ) & 10 & - \\
\hline $\begin{array}{l}6 \\
64 \\
640 \\
641\end{array}$ & $\begin{array}{l}\text { Transport and } \\
\text { communication work } \\
\text { Motor vehicle drivers } \\
\text { Bus/taxi drivers } \\
\text { Lorry drivers }\end{array}$ & $\begin{array}{r}36 \\
29 \\
5 \\
23\end{array}$ & $\begin{array}{c}76(47 \text { to } 94) \\
100(62 \text { to } 137) \\
47(6 \text { to } 88) \\
115(68 \text { to } 162)\end{array}$ & $\begin{array}{r}170 \\
97 \\
28 \\
66\end{array}$ & $\begin{array}{l}47(24 \text { to } 71) \\
65(28 \text { to } 101) \\
\overline{70}(9 \text { to } 131)\end{array}$ \\
\hline $\begin{array}{l}7 / 8 \\
73 \\
731 \\
737 \\
75 \\
751 \\
752 \\
753 \\
754 \\
755 \\
756 \\
759 \\
76 \\
763 \\
77 \\
772 \\
777 \\
78 \\
781 \\
783 \\
79 \\
793 \\
794 \\
799\end{array}$ & $\begin{array}{l}\text { Production work } \\
\text { Metal processing work } \\
\text { Furnaceman } \\
\text { Metal casters } \\
\text { Metal machine work } \\
\text { and building metal work } \\
\text { Tool makers } \\
\text { Machinery fitters } \\
\text { Machine assemblers } \\
\text { Sheet metal workers } \\
\text { Plumbers } \\
\text { Welders } \\
\text { Metal workers NEC } \\
\text { Electrical work } \\
\text { Electrical repairmen } \\
\text { Wood work } \\
\text { Wood processing workers } \\
\text { Wood working } \\
\text { machine operators } \\
\text { Painting and floor } \\
\text { laying work } \\
\text { Building painters } \\
\text { Spray painters } \\
\text { Other building work } \\
\text { Concrete workers } \\
\text { Carpenters } \\
\text { Construction workers NEC }\end{array}$ & $\begin{array}{r}395 \\
24 \\
6 \\
6 \\
\\
140 \\
10 \\
9 \\
71 \\
12 \\
7 \\
54 \\
10 \\
11 \\
5 \\
36 \\
10 \\
\\
14 \\
\\
35 \\
18 \\
11 \\
50 \\
16 \\
22 \\
5\end{array}$ & $\begin{array}{l}161(145 \text { to } 176) \\
375(222 \text { to } 540) \\
702(140 \text { to } 1264) \\
567(113 \text { to } 1021) \\
197(165 \text { to } 229) \\
78(30 \text { to } 126) \\
106(37 \text { to } 175) \\
110(63 \text { to } 157) \\
210(91 \text { to } 329) \\
106(27 \text { to } 185) \\
647(474 \text { to } 820) \\
137(52 \text { to } 222) \\
43(17 \text { to } 68) \\
244(30 \text { to } 458) \\
324(216 \text { to } 432) \\
455(217 \text { to } 693) \\
354(169 \text { to } 539) \\
352(232 \text { to } 475) \\
280(151 \text { to } 409) \\
599(245 \text { to } 953) \\
143(103 \text { to } 182) \\
240(122 \text { to } 358) \\
151(87 \text { to } 215) \\
50(6 \text { to } 94)\end{array}$ & $\begin{array}{r}820 \\
21 \\
3 \\
4 \\
\\
237 \\
43 \\
64 \\
28 \\
19 \\
22 \\
28 \\
24 \\
86 \\
7 \\
36 \\
14 \\
13 \\
\\
33 \\
21 \\
6 \\
117 \\
22 \\
49 \\
33\end{array}$ & $\begin{array}{l}160(138 \text { to } 178) \\
250(167 \text { to } 500) \\
- \\
165(128 \text { to } 203) \\
46(6 \text { to } 86) \\
97(19 \text { to } 175) \\
229(87 \text { to } 370) \\
151(39 \text { to } 263) \\
118(15 \text { to } 221) \\
690(476 \text { to } 904) \\
106(13 \text { to } 199) \\
- \\
208(105 \text { to } 313) \\
- \\
278(72 \text { to } 484) \\
306(181 \text { to } 431) \\
293(133 \text { to } 452) \\
590(181 \text { to } 999) \\
142(95 \text { to } 190) \\
220(76 \text { to } 363) \\
185(102 \text { to } 268) \\
-\end{array}$ \\
\hline $\begin{array}{l}82 \\
822 \\
84 \\
842 \\
87 / 88\end{array}$ & $\begin{array}{l}\text { Food processing and } \\
\text { tobacco work } \\
\text { Bakers } \\
\text { Pulp and paper work } \\
\text { Paper mill workers } \\
\text { Material handling, }\end{array}$ & $\begin{array}{r}26 \\
16 \\
18 \\
8\end{array}$ & $\begin{array}{l}391(242 \text { to } 545) \\
775(425 \text { to } 175) \\
386(173 \text { to } 54) \\
297(91 \text { to } 503)\end{array}$ & $\begin{array}{r}22 \\
5 \\
16 \\
9\end{array}$ & $\begin{array}{l}381(190 \text { to } 571) \\
884(384 \text { to } 1384) \\
333(133 \text { to } 533) \\
271(33 \text { to } 507)\end{array}$ \\
\hline $\begin{array}{l}873 \\
882 \\
83\end{array}$ & $\begin{array}{l}\text { package, and storage work } \\
\text { Truck operators } \\
\text { Storemen } \\
\text { Chemical and plastic }\end{array}$ & $\begin{array}{r}29 \\
7 \\
16\end{array}$ & $\begin{array}{l}100(66 \text { to } 135) \\
104(27 \text { to } 181) \\
131(67 \text { to } 195)\end{array}$ & $\begin{array}{l}96 \\
22 \\
41\end{array}$ & $\begin{array}{l}86(44 \text { to } 131) \\
1 \overline{15}(40 \text { to } 190)\end{array}$ \\
\hline $\begin{array}{l}835 \\
839\end{array}$ & $\begin{array}{l}\text { production work } \\
\text { Plastic product workers } \\
\text { Chemical process } \\
\text { workers NEC }\end{array}$ & $\begin{array}{r}29 \\
9 \\
6\end{array}$ & $\begin{array}{l}464(302 \text { to } 619) \\
344(119 \text { to } 569) \\
585(117 \text { to } 1053)\end{array}$ & $\begin{array}{r}26 \\
8 \\
4\end{array}$ & $\begin{array}{l}429(238 \text { to } 619) \\
734(91 \text { to } 1377)\end{array}$ \\
\hline $\begin{array}{l}9 \\
93 \\
931\end{array}$ & $\begin{array}{l}\text { Service work } \\
\text { Caretaking and } \\
\text { cleaning work } \\
\text { Building caretakers }\end{array}$ & $\begin{array}{r}24 \\
94 \\
6\end{array}$ & $\begin{array}{l}38(32 \text { to } 79) \\
56(19 \text { to } 93) \\
54(11 \text { to } 97)\end{array}$ & $\begin{array}{r}170 \\
54 \\
37\end{array}$ & $\begin{array}{l}35(14 \text { to } 57) \\
-\end{array}$ \\
\hline Total & & 587 & 91 (84 to 98$)$ & 2150 & 75 (67 to 83$)$ \\
\hline
\end{tabular}

*All cases are included in the one digit groups. In the two digit and three digit groups, at least five cases are required to be tabulated.

†Based on the nordic occupational classification. 
occupations in the general working population were obtained from the 1990 national census, in which the subjects have also been classified according to the Nordic occupation classification.

The annual reporting rate was calculated by dividing the mean annual number of cases by the number of people in the workforce in each occupation. Men and women were separated in the analyses, and there was also a separate analysis of subjects 20 to 44 years old. The rates presented are not proper incidences, because the year used is the year of reporting and not the year of the diagnosis. All rates are expressed million working people per year.

For analysis at least five cases were required in the occupational groups (two digit level) and specific occupations (three digit level). For both sexes the rates for all occupational groups at the one digit level are presented. In general the results have been presented at the level of specific occupations (three digit level), but in some cases, at the two digit level. 95\% Confidence intervals (95\% CI) are given for all rates, based on a Poisson distribution.

\section{Results}

In $1990-2$, a total of 1010 cases of occupational asthma were reported, 587 men and 423 women. In 1990 there were 408 cases, 339 cases in 1991, and 263 cases in 1992. The crude annual reporting rate was $80 /$ million (95\% CI 70 to 90 ) based on a working population of $4 \cdot 2$ million.

For all men, the annual reporting rate was 91/million ( $95 \%$ CI 84 to 98 ). For men 20 to 44 years old it was $75 /$ million ( $95 \%$ CI 67 to 83 ), and it was $117 /$ million (95\% CI 113 to 131) for men 45 to 64 years old.

For all women the annual reporting rates were $70 /$ million ( $95 \%$ CI 63 to 77 ), 93/million (95\% CI 80 to 106) for women 45 to 64 years old, and 56/million (95\% CI 49 to 63) for women 20 to 44 years old.

Table 1 shows the reporting rates in men. Annual rates $>400 /$ million occurred among bakers (775/million), furnacemen (702/million), welders $(647 /$ million), spray painters (599/million), chemical process workers (585/million), metal casters (567/million), and wood processing workers (455/million).

Table 2 Total number and annual self reporting rate (case/milion) of occupational asthma 1990-2 among Swedish women *

\begin{tabular}{|c|c|c|c|c|c|}
\hline \multirow[b]{2}{*}{$\begin{array}{l}\text { Digit } \\
\text { codet }\end{array}$} & \multirow[b]{2}{*}{$\begin{array}{l}\text { Occupation or } \\
\text { occupational group }\end{array}$} & \multicolumn{3}{|c|}{ Age 20-64 } & \multirow{2}{*}{$\frac{\text { Age } 20-44}{\text { Rate }(95 \% C I)}$} \\
\hline & & $n$ & Rate $(95 \%$ CI) & $\begin{array}{l}\text { Population } \\
(\times 1000)\end{array}$ & \\
\hline $\begin{array}{l}0 \\
012 \\
03\end{array}$ & $\begin{array}{l}\text { Professional, technical } \\
\text { and related work } \\
\text { Laboratory technicians } \\
\text { Educational work }\end{array}$ & $\begin{array}{l}57 \\
6 \\
38\end{array}$ & $\begin{array}{l}63(51 \text { to } 87) \\
251(50 \text { to } 452) \\
70(48 \text { to } 93)\end{array}$ & $\begin{array}{l}52 \\
8 \\
180\end{array}$ & $\begin{array}{l}\frac{55}{47}(34 \text { to } 76) \\
472 \text { to } 76)\end{array}$ \\
\hline $\begin{array}{l}1 \\
10\end{array}$ & $\begin{array}{l}\text { Health, nursing } \\
\text { and social work } \\
\text { Health and nursing work }\end{array}$ & $\begin{array}{l}94 \\
38\end{array}$ & $\begin{array}{l}52(42 \text { to } 70) \\
52(36 \text { to } 68)\end{array}$ & $\begin{array}{l}600 \\
244\end{array}$ & $\begin{array}{l}46(34 \text { to } 59) \\
40(22 \text { to } 59)\end{array}$ \\
\hline $23 / 24$ & $\begin{array}{l}\text { Administrative, } \\
\text { managerial and } \\
\text { clerical work } \\
\text { Accounting and } \\
\text { clerical work }\end{array}$ & $\begin{array}{l}40 \\
30\end{array}$ & $\begin{array}{l}30(22 \text { to } 42) \\
36(23 \text { to } 49)\end{array}$ & $\begin{array}{l}450 \\
277\end{array}$ & $\begin{array}{l}22(11 \text { to } 33) \\
23 \text { ( } 9 \text { to } 37)\end{array}$ \\
\hline $\begin{array}{l}3 \\
33\end{array}$ & $\begin{array}{l}\text { Sales work } \\
\text { Sales work (goods) }\end{array}$ & $\begin{array}{l}26 \\
28\end{array}$ & $\begin{array}{l}43(27 \text { to } 60) \\
66(43 \text { to } 90)\end{array}$ & $\begin{array}{l}200 \\
28\end{array}$ & $\begin{array}{l}42(12 \text { to } 62) \\
73(30 \text { to } 115)\end{array}$ \\
\hline $\begin{array}{l}4 \\
400 \\
412\end{array}$ & $\begin{array}{l}\text { Agricultural, forestry } \\
\text { and fishing work } \\
\text { Farmers } \\
\text { Dairy and } \\
\text { poultry farm workers }\end{array}$ & $\begin{array}{l}18 \\
10 \\
5\end{array}$ & $\begin{array}{l}200(112 \text { to } 292) \\
203(77 \text { to } 329) \\
602(74 \text { to } 1130)\end{array}$ & $\begin{array}{l}30 \\
16 \\
3\end{array}$ & $\begin{array}{l}389(194 \text { to } 583) \\
425 \text { (110 to } 740) \\
665 \text { (82 to } 1248)\end{array}$ \\
\hline 5 & $\begin{array}{l}\text { Mining, quarrying } \\
\text { and petroleum } \\
\text { extraction work }\end{array}$ & - & - & - & - \\
\hline 6 & $\begin{array}{l}\text { Transport and } \\
\text { communication work }\end{array}$ & 10 & 256 (97 to 415$)$ & 20 & $67(0$ to 427$)$ \\
\hline $\begin{array}{l}7 / 8 \\
716 \\
75\end{array}$ & $\begin{array}{l}\text { Production work } \\
\text { Sewers } \\
\text { Metal machine }\end{array}$ & 8 & $\begin{array}{l}259(210 \text { to } 309) \\
223(68 \text { to } 378)\end{array}$ & $\begin{array}{l}150 \\
12\end{array}$ & $223(170$ to 277$)$ \\
\hline $\begin{array}{l}759 \\
77\end{array}$ & $\begin{array}{l}\text { and building work } \\
\text { Metal workers NEC } \\
\text { Wood work }\end{array}$ & $\begin{array}{l}24 \\
6 \\
10\end{array}$ & $\begin{array}{l}291(171 \text { to } 400) \\
286(57 \text { to } 515) \\
494(181 \text { to } 771)\end{array}$ & $\begin{array}{l}28 \\
7 \\
7\end{array}$ & $\begin{array}{l}263(123 \text { to } 386) \\
-\end{array}$ \\
\hline $\begin{array}{l}881 \\
83\end{array}$ & $\begin{array}{l}\text { Packers } \\
\text { Chemical and platic }\end{array}$ & 11 & $262(107$ to 417$)$ & 14 & 249 (64 to 433 ) \\
\hline $\begin{array}{l}835 \\
839\end{array}$ & $\begin{array}{l}\text { production work } \\
\text { Plastic production workers } \\
\text { Chemical process } \\
\text { workers NEC }\end{array}$ & $\begin{array}{l}17 \\
9 \\
6\end{array}$ & $\begin{array}{l}629(334 \text { to } 925) \\
566(196 \text { to } 936) \\
952(190 \text { to } 1714)\end{array}$ & $\begin{array}{l}17 \\
5 \\
2\end{array}$ & $\begin{array}{l}666(278 \text { to } 1056) \\
844(293 \text { to } 1395) \\
-\end{array}$ \\
\hline $\begin{array}{l}9 \\
912 \\
913 \\
932 \\
941\end{array}$ & $\begin{array}{l}\text { Service work } \\
\text { Cooks } \\
\text { Kitchen assistants } \\
\text { Cleaners } \\
\text { Hairdressers }\end{array}$ & $\begin{array}{l}72 \\
7 \\
11 \\
36 \\
6\end{array}$ & $\begin{array}{l}113(86 \text { to } 139) \\
116(30 \text { to } 202) \\
68(28 \text { to } 108) \\
133(90 \text { to } 176) \\
129(26 \text { to } 232)\end{array}$ & $\begin{array}{l}250 \\
20 \\
57 \\
94 \\
11\end{array}$ & $\begin{array}{l}100(63 \text { to } 137) \\
\frac{-}{105}(52 \text { to } 158) \\
-\end{array}$ \\
\hline Total & & $423 \ddagger$ & 70 (63 to 77$)$ & 2000 & 56 (49 to 63$)$ \\
\hline
\end{tabular}

*All cases are included in the one digit groups. In the two digit and three digit groups, at least five cases are required to be tabulated.

†Based on nordic occupational classification. ‡One case is unclassified. 
Table 2 shows the annual reporting rates for women and annual rates $>400 /$ million were found for chemical process workers not elsewhere classified (952/million), dairy and poultry farm workers (602/million), plastic production workers (566/million), and wood workers (494/million).

The rates varied between the years-for instance, for the years 1990-2 the rates for male bakers were $294 /$ million, $1029 /$ million, and $1029 /$ million, male welders were $1074 /$ million, $666 /$ million, and $333 /$ million, and male spray painters were $163 /$ million, $983 /$ million, and $656 /$ million.

\section{Discussion}

The overall annual rate of self reporting occupational asthma in Sweden was 91/million for men and 70/million for women. These rates are higher than in the United Kingdom, but lower than in Finland. The specific occupations with the highest rates were mainly occupations in which increased risks of asthma have already been described, such as bakers, chemical processors, plastic workers, and spray painters.

The diagnosis of asthma has not been validated or confirmed in any way. The diagnosis is based on self reporting, and self reported disease may evoke scepticism. To be classified as asthma the subject had to report "asthma". Reporting of asthma-like symptoms was not considered sufficient. Self reported asthma is in general an operational definition of asthma with high specificity and low sensitivity. ${ }^{10}$

The reporting rate was higher in older subjects. Similar findings have been made by others. ${ }^{25}$ This may be for socioeconomic reasons-that is, older workers keep their jobs despite their symptoms and seek medical care at a later stage, whereas young subjects change work if symptoms develop. However, the cumulative occupational exposure to asthmatic agents increases with age, and hence the risk of developing occupational asthma increases. In a Canadian study it was found that workers with a longer duration of employment ( $>10$ years) were more than six times as likely to develop asthma in their current employment. ${ }^{\prime \prime}$ Also, susceptibility may increase with age.

Self reporting of asthma is sensitive to misclassification, which increases with age. ${ }^{10}$ For this reason $I$ also analysed rates for the age group 20 to 44, which showed lower rates but the same risk pattern. This bias is probably independent of the subjects' exposure status, although smoking habits are associated with occupation. Hence, in occupations with a higher prevalence of smoking such a misclassification may be common. Subjects just reporting asthma-like symptoms are not included in this analysis. Self reported asthma-like symptoms and true asthma are often misclassified, hence they were not included in this study. ${ }^{10}$

Subjects with pre-existing disease may report the aggravation of their asthma as an occupational asthma. This may explain the reported cases in occupations with exposure to irritants but without any known exposure that causes asthma. ${ }^{12}$ Examples of such occupations are welders (with a reservation about stainless steel welders), loggers, and cooks.

In occupations with exposure to organic dust-such as farmers and woodworkersasthma and allergic alveolitis may be misclassification.

It is important to realise that results from self reported occupational asthma can never reach the accuracy of a proper clinical diagnosis, but at group level, it provides a measure of asthma that can be used for generating hypotheses or confirming existing knowledge. The risk pattern in this study is similar to that found in other surveillance systems, and supports the validity of the methods used.

The denominator used in calculations of the rates is the workforce from the 1990 census. In the early 1990s a recession began in Sweden and by 1992 the workforce had decreased by $5.7 \%$. The reduction was most notable in the construction and manufacturing industries. Hence, the rates, especially from construction and manufacturing, are too low. But despite the increasing unemployment among construction workers, the rates did not increase in 1992 compared with 1990 to 1991 . Actually, the overall reporting rate has continued to decrease after 1993, probably due to a change towards less favourable compensation for occupational asthma and other work related disorders.

The overall reporting rate for occupational asthma was $80 /$ million in 1990 in this study. This is higher than the rates from the United Kingdom (24/million for men and 13/million for women) ${ }^{5}$ and from the West Midlands Health Region of the United Kingdom (sexes combined, 43/million). ${ }^{13}$ The United Kingdom rates are, however, likely to be considerable underestimates. ${ }^{713}$ In comparison with Finland, a country with similar socioeconomic conditions to Sweden, the results from the present study indicate an underreporting of occupational asthma. The overall incidence of occupational asthma in Finland was $152 /$ million in $1990 .^{1}$ It must, however, be realised that about $30 \%$ of the Finnish cases of occupational asthma are due to sensitisation to cow dander. ${ }^{14}$ Finnish farmers tend to brush their cows daily. This is very uncommon in Sweden.

The rates for the different specific occupations in this study mainly reflect those occupations with well recognised causes of occupational asthma, such as bakers, spray painters, chemical processors, plastic workers, and poultry workers.

The high rates among the group of workers in foundries and steel mills, furnacemen, and metal casters is less well recognised. In Sweden, this group consists mainly of steel mill workers, although there is one aluminium smelter. The furnacemen (at steel mills) are mainly exposed to a vide variety of inorganic dust, but no obvious agents causing asthma have been identified. The metal casters, on the other hand, who include workers from foundries of different sizes, are exposed to iso- 
cyanates, various amines, and formaldehyde, as well as the exposure to inorganic dust $(\mathrm{H}$ Westberg, personal communication). Among the metal casters, the subgroup core makers are especially exposed to isocyanates, because the cores are made from a mixture of sand and a binder containing isocyanates (the "cold box" method). It is also of interest that the United Kingdom surveillance system found an increased rate for foundry workers. ${ }^{13}$

Male welders had a high rate of reporting occupational asthma. This was not found in other surveys, and in this study it may merely reflect aggravation of pre-existing disease, as welders are exposed to respiratory irritants. The existing publications do not support an increased risk among welders, ${ }^{15}$ but it is important to realise that there are still no adequate epidemiological studies in this field. Welding in stainless steel implies exposure to chromium IV, which is known to cause asthma. There are also reports of asthma among stainless steel welders. ${ }^{16-19}$ Two recent small studies have found a slightly increased risk of asthma among welders, with no difference between welding in stainless steel and plain steel..$^{20}$

Male and female woodworkers had high reporting rates. In Sweden woodworkers use mainly pine and spruce, and hardwood is rare. Wood processing workers are exposed to fresh wood, terpenes, and microorganisms. We have previously found increased mortality from asthma in this group. ${ }^{22}$ Existing publications do not support a relation between asthma and exposure to Scandinavian tree species, ${ }^{23}$ although there are still no proper epidemiological studies.

The reporting rates of occupational asthma in Sweden have previously been analysed for the period $1984-6 .{ }^{24} \mathrm{High}$ rates were found among bakers $(800 /$ million), chemical process workers (800/million), and plastic product workers (500/million). The analyses were not separated by sex.

In conclusion, despite the influence of reporting bias, analysis of this Swedish self reported surveillance system for occupational asthma gave some important information. High risk occupations, as in other countries, include bakers, chemical processors, and plastic workers. This is well recognised, and highlights the need for preventive measures in these occupations. High risks were also found in occupations with less well recognised risks of asthma, such as welders, woodworkers, and foundry workers. This may reflect reporting of aggravated pre-existing disease, but a real increased risk cannot be ruled out and further aetiological studies are needed.

The study was supported by the Swedish Council for Worklife Research. I am also grateful to Börje Bengtsson, the Swedish Register for Reported Occupational Diseases (SRROD), for generous support.

Nordman $\mathrm{H}$. Occupational asthma-time for prevention Scand $\mathcal{F}$ Work Environ Health 1994;20:108-15.

2 Keskinen H, Alanko K, Saarinen L. Occupational asthma in Finland. Clin Allergy 1978;8:569-72.

3 Gannon PFG, Burge PS. A preliminary report of a surveillance scheme of occupational asthma in the West Midlands. Br F Ind Med 1991;48:579-82.

4 Meredith SK, Taylor VM, McDonald JC. Occupational respiratory disease in the United Kingdom 1989: a report to the British Thoracic Society and the Society of Occupational Medicine by the SWORD project group. Br f Ind Med 1991;48:292-8.

5 Meredith S. Reported incidence of occupational asthma in the United Kingdom, 1989-90. If Epidemiol Community Health 1993;47:459-63.

6 Matte TD, Hoffman RE, Rosenman KD, Stanbury M Surveillance of occupational asthma under the SENSOR model. Chest 1990;98:173s-8s.

7 Seaton A. Surveillance of work related and occupational respiratory disease-SWORD. Thorax 1991;46:548.

8 Andersson E, Torén K. Pleural mesotheliomas are underreported as occupational cancer in Sweden. Am $\mathcal{F}$ Ind Med 1995;27:577-80.

9 World Health Organisation. International standard classification of occupations. Geneva: WHO, International Labour Organisation, 1958 .

10 Torén K, Brisman J, Järvholm B. Asthma and asthma-like symptoms in adults assessed by questionnaires. A literasymptoms in adults assessed by quest
ture review. Chest 1993;104:600-8.

11 Siracusa A, Kennedy SM, DyBuncio A, Lin FJ, Marabini A, Chan-Yeung M. Prevalence and predictors of asthma in working groups in British Columbia. Am $\mathcal{F}$ Ind Med 1995;28:411-23.

12 Tarlo SM, Liss G, Corey P, Broder I. A workers' compensation claim population for occupational asthma. Comparison of subgroups. Chest 1995;107:634-41.

13 Gannon PFG, Sherwood Burge P. The SHIELD scheme in the West Midlands Region, United Kingdom. Br $\mathcal{F}$ Ind Med 1993;50:791-6.

14 Kanerva L, Jolanki R, Toikkanen J. Frequencies of occupational allergic diseases and gender differences in Finland. Int Arch Occup Environ Health 1994;66:111-6.

15 Sferlazza SJ, Becket WS. The respiratory health of welders. Am Rev Respir Dis 1991;143:1134-48.

16 Keskinen H, Kalliomäki PL, Alanko K. Occupational asthma due to stainless steel welding fumes. Clin Allergy asthma due to s.

17 Dahl R, Millelsen HB. Asthma bronkiale og kromallergi udlöst af svejsning af rustfritt stål. Ugeskr Laeger 1982;144:801-2. (In Danish.)

18 Björnerem H, Thomassen LM, Wergeland E. Sveiserastma. En kuriositet? eller-? Tidskr Nor Laegeforen 1983;103:1286-8. (In Norwegian.)

19 Moller DR, Brooks SM, Bernstein DI, Cassedy K, Enrione $M$, Bernstein IL. Delayed anaphylactoid reaction in a worker exposed to chromium. F Allergy Clin Immunol 1986;77:451-6.

20 Antti-Poika $M$, Nordman $H$, Koskenvuo $M$, Kaprio J, Jalava M. Role of occupational exposure to airway irritants in the development of asthma. Int Arch Occup tants in the development of as
Environ Health 1992;64:195-200.

21 Wang ZP, Larsson K, Malmberg P, Sjögren B, Hallberg B$\mathrm{O}$, Wrangskog K. Asthma, lung function, and bronchial responsiveness in welders. Am $\mathcal{F}$ Ind Med 1994;26: 741-54.

22 Torén K, Hörte L-G, Järvholm B. Occupation and smoking adjusted mortality due to asthma among Swedish men. Br F Ind Med 1991;48:323-6.

23 Goldsmith DF, Shy CM. Respiratory health effects from occupational exposure to wood dusts. Scand $\mathcal{f}$ Work Environ Health 1988;14:1-15.

24 Malmberg P. Yrkeslungsjukdomar. Rapport till Arbetsmiljökommissionen. Stockholm: Sverige, 1990. (In Swedish.) 